The Quarterly Journal of Austrian Economics

Volume 23 | NO.3-4 | 462-498 | Fall/Winter 2020 WWW.QJAE.ORG

\title{
ENTREPRENEURIAL EMPOWERMENT: YOU Are Only as Good as Your EMployees
}

\author{
DeSMOND $\mathrm{NG}^{*}$
}

JEL Classification: B53, M12, M54

Aвstract: As employees are increasingly recognized as an important source of ideas and inspiration, contemporary leadership research finds that the central task of leaders is to empower employees to realize their skills and talents to achieve an organizations' visions and goals. Drawing on this leadership premise, this study develops the concept of entrepreneurial empowerment (EE). EE has structural and psychological dimensions that empower employees to utilize their knowledge to solve the internal Hayekian knowledge problem. EE introduces an endogenous discovery process in which entrepreneurial leaders play a central role in empowering employees to use their localized knowledge. This entrepreneurial discovery process offers opportunities to adapt and innovate using the knowledge experiences of employees. This study underscores that a venture's success is not tied to an entrepreneur's inspirational ideas (or, more broadly, their asymmetric knowledge experiences), but to their ability to inspire ideas from all levels of their business hierarchy.

"No company, small or large, can win over the long run without energized employees who believe in the mission and understand how to achieve it." - Jack Welch, General Electric

\footnotetext{
* Desmond Ng (dng@tamu.edu) is associate professor of agribusiness and strategy management at Texas A\&M University. The author would like to thank the special guest editor, Professor Bylund, and the two anonymous reviewers for their constructive comments and suggestions.
} 
$\mathrm{T}$ o succeed in an increasingly complex and changing market environment, ventures can no longer compete on the basis of their leader's capabilities, knowledge, talents, and vision alone (e.g., Cowen and Parker 1997; Foss, Foss, and Klein 2007; Rigtering, Weitzel, and Muehlfeld 2019). Ideas to develop new products and services can come from anywhere, from loyal customers, blog spheres, supply chain partners, social media, and above all employees (Rigtering, Weitzel, and Muehlfeld 2019). For instance, $3 \mathrm{M}$ established a culture in which employees are encouraged to develop "home-grown" solutions to addressing their customers' needs. These home-grown solutions transformed a small-scale mining venture into a leading material sciences company and have earned the company a spot on Fast Company's Best Workplace for Innovators list (Rubinson 2009; FastCo Works 2019). Companies such as $3 \mathrm{M}$ underscore that in order to succeed entrepreneurs must be able to adapt to ideas that extend beyond their own (e.g., Lee, Lee, and Pennings 2001; Rigtering, Weitzel, and Muehlfeld, 2019; Sarasvathy 2001). Adaptation promotes an integration of different knowledge experiences that enables the venture to respond to changing market conditions and opportunities not previously considered (e.g., Hargadon and Sutton 1997; Sarasvathy 2001; Sullivan and Marvel 2011). Hence, although successful ventures are commonly attributed to an entrepreneur's ideas, talents, and vision (e.g., Witt 1998, 1999), entrepreneurs today face increasing demands to adapt their ideas to the knowledge experiences of others (see Cowen and Parker 1997; Rigtering, Weitzel, and Muehlfeld 2019; Sarasvathy 2001).

Although the role of Austrian economics in contemporary entrepreneurship research remains a subject of much discussion and debate (Klein and Bylund 2014), Austrian economics is particularly suited to addressing the challenges faced by today's entrepreneurs. According to the subjective tenets of Austrian economics, entrepreneurs operate in a sea of subjective experiences in which they adapt by mobilizing these knowledge experiences to address opportunities not currently met by the market. This adaption has been widely understood as the Hayekian knowledge problem: the problem of how to utilize knowledge experiences that are broadly distributed among the productive members of society. F. A. Hayek 
(1945) argued that the productive members of society, such as employees, have a knowledge of the "particular circumstances of time and place" (521). This knowledge involves an employee's particular understandings of the special circumstances, challenges, and local conditions of their job. Hayek (1945) argued that a single mind, such as that of a centrally planner, cannot offer an adaptation that can utilize this "knowledge of particular circumstance of time and place," because this knowledge is highly localized to an employees' experiences. He instead argued that employees are in the best position to utilize this knowledge because their understandings of the special circumstances of their job offered employees or "arbitrageurs" (522) opportunities to exploit local price differentials not known by others. This arbitrage function was later formalized by Israel M. Kirzner's (1979, 2009, 2019) concept of the alert entrepreneur. Alertness involves discovering price arbitrage opportunities by bringing into use factors of productions at a price less than their valued uses. Specifically, as employees are key factors of a firm's production, alertness solves the Hayekian knowledge problem, because the alert entrepreneur is incentivized to bring into use their employee's knowledge to discover the price arbitrage opportunities of the market.

Although Kirzner (1979) has been credited with solving the Hayekian knowledge problem (Elert and Henrekson 2019; Foss and Klein 2016), the concept of alertness implicitly assumes that an employee's knowledge can be centralized under an entrepreneur's leadership. This leadership involves a position of authority in which the entrepreneur has the power to institute their vision over their employees (Shamir, House, and Arthur, 1993; Witt, 1998). In this position, however, an entrepreneur cannot readily identify their employees' knowledge, because the entrepreneur's authority is removed from their employees' day-to-day experiences. This is consistent with Hayek (1945), who argued that employees are best suited to making decisions on how to allocate their time, resources, and efforts in dealing with their daily operational challenges because employees are most familiar with the circumstances facing them in carrying out their tasks. Hence, the challenge facing the entrepreneur is that their inability to centralize their employees' knowledge introduces an internal Hayekian knowledge problem (see also Elert and Henrekson 2019; Foss 1997; Foss, Foss, and Klein 2007) of: how 
an entrepreneur in a position of authority can utilize the different knowledge experiences of their employees when employees are in the best position to know their valued contributions?

This study's objective is to develop a concept of "Entrepreneurial Empowerment" (EE) to address this internal Hayekian knowledge problem. Leadership research has widely recognized that employees are an important source of ideas and inspirations (Argyris 1998, Foss, Foss, and Klein 2007; Gagne and Edward 2005; Govindarajan and Srikanth 2013; Lee and Koh 2001; Lee, Willis, and Tian 2018; Rigtering, Weitzel, and Muehlfeld 2019). The task of the leader, then, is to empower employees to realize their skills and talents to achieve the organization's mission and goals (Argyris 1998; Cowen and Parker 1997; Foss, Foss, and Klein 2007; Lee and Koh 2001; Lee, Willis, and Tian 2018). Drawing on this leadership premise, this article develops the concept of entrepreneurial empowerment (EE). EE involves a leadership task of organizing a firm's internal decision-making process in which employees are delegated a decision-making authority that advances the entrepreneur's mission. Specifically, EE has structural and psychological dimensions that empower employees to utilize their knowledge of particular circumstances of time and place to solve the internal Hayekian knowledge problem. By solving this problem, EE offers opportunities for the entrepreneurial leader to adapt to and innovate using the knowledge experiences of their employees in ways that cannot be achieved through centralized direction. Propositions surrounding this EE concept are offered. One major contribution of the concept of $\mathrm{EE}$ is that the entrepreneurial leader offers an internal organization that empowers employees to solve an internal Hayekian knowledge problem and thus advances an entrepreneur's mission or goals. As result, this study offers a theory of internal organization that opens up the "black box" of Austrian economics (Foss and Klein, 2012 70).

\section{UNITS OF ANALYSIS, DEFINITIONS AND ASSUMPTIONS}

Before developing this study's conceptual model, it is important to outline its definitions, assumptions, and units of analysis. According to leadership research, empowerment is defined by an 
"increased individual motivation at work through the delegation of authority to the lowest level in an organization where a competent decision can be made" (Seibert, Silver, and Randolph 2004, 332). As entrepreneurs often hold positions of leadership, an entrepreneur's leadership involves the power to delegate authority to the lower levels of their decision hierarchy (e.g., Cowen and Parker 1996; Foss, Foss, and Klein 2007; Shamir, House, and Arthur 1993; Witt 1998). In addition, this leadership also involves an ability to motivate and shape employees' behavior and attitudes (Ashford and Sitkin 2019; Shamir, House, and Arthur 1993; Witt 1998), as well as empowering the psychological states or intrinsic motivations of their employees (Lee and Koh 2001; Lee, Willis, and Tian 2018). With these distinctions, entrepreneurial leadership is defined by structural and psychological dimensions that involve empowering employees through a delegation of authority to all levels of the decision hierarchy and an ability to appeal to employees' intrinsic motivations. This definition assumes that employees' empowerment is "influenced or caused" by an entrepreneur's leadership. This assumption is consistent with Lee and Koh (2001), in which empowerment is understood as the "behavior of a supervisor who empowers his/her subordinates" (685). With this assumption, the unit of analysis is focused on the structural and psychological relationships that exist between the entrepreneurial leader and their employees (Lee and Koh 2001). Specifically, this study focuses on the leadership of senior members and not supervisory managers, because leadership studies find that hierarchically organized businesses are subject to social learning processes in which a leader's actions can have a "cascading effect" that impacts the lowest-level employees of their decision hierarchy (Liu, Liao, and Loi 2012; Shamir, House and Arthur 1993; Witt 1998).

\section{Empowerment and Hayek's Libertarian View of Markets}

Although the concept of empowerment is commonly explained in terms of a leadership function (e.g., Lee and Koh 2001, Spreitzer 2008), empowerment also shares a similar political economic orientation to the libertarian tenets of F. A. Hayek (1945, 1952). As in Hayek (1945), empowerment is a political exercise that rejects the "politics in command" of centrally planned/socialist economies 
(Mohanty 1995, 1434). Empowerment involves granting freedom and equality by transferring power from an upper level agency, such as a central planner or authority, to people below (Mohanty 1995). This empowerment involves affirming an individual's freedoms by strengthening their capacity for self-governance, autonomy and self-determination and is an important economic and political goal of Western societies (Mohanty 1995). Similarly, Hayek's notion of "true libertarianism" is founded on a political economic philosophy that celebrates the benefits of individual choice and freedom. This libertarianism appeals to the collective powers of a decentralized decision-making process, as Hayek (1952) shows:

\footnotetext{
"many of the greatest things man has achieved are not the result of consciously directed thought, and still less the product of deliberately coordinated effort of many individuals, but of a process in which the individual plays a part which he can never fully understand. They are greater than any individual precisely because they result from the combination of knowledge more extensive than single mind can master." (84)
}

Although empowerment shares a similar political-economic orientation to Hayek's true libertarianism, their motivations for rejecting the powers of a central authority differ. Empowerment rejects the "politics in command," because of the corruptive tendencies of government (Mohanty 1995). Hayek's true libertarianism (1945) rejects central planning on grounds of its limited ability to process decentralized information (see also Klein 1996). Hayek (1945) argued that the allocation of societal resources requires centralizing dispersed knowledge experiences that cannot be fully known by a central authority. This dispersed knowledge is held by the "man on the spot," consisting of workers or employees. Each employee has a knowledge of the particular "circumstances of time and place," or more simply put, knowledge of the particulars. This knowledge consists of the particular work challenges and local work conditions faced by an employee. For instance, a real estate employee's ability to develop their clientele is dependent on their unique understandings of the amenities in a neighborhood (i.e., quality of schools, relative affluence of homeowners, crime rates, general history of the neighborhood, etc.). The man on the spot/employee is better suited to utilizing this knowledge of the particulars than a centrally planned actor, because the man on 
the spot is most familiar with the unique circumstances of their job (Hayek 1945). As a result, Hayek (1945) argued that the chief economic problem is not concerned with how a central planner can allocate the scarce resources of society, but rather a knowledge problem "of how to secure the best use of resources known to any of the members of society, for ends whose relative importance only these individuals know" (520).

\section{II.ALERT ENTREPRENEURSHIP AND A SOLUTION TO HAYEK'S KNOWLEDGE PROBLEM}

In sharing Hayek's (1945) commitments to freedom and liberty, Kirzner's (1979) concept of alertness offered a mechanism key to solving the Hayekian knowledge problem (Foss and Klein 2016). Alertness is defined as "an attitude of receptiveness to available, but hitherto overlooked, opportunities" (Yu 2001, 51). This receptiveness involves a psychological predisposition for discovering price arbitrage opportunities not seen by others (Kirzner 1979). Alertness involves discovering price arbitrage opportunities where the entrepreneur assembles their factors of production at a price that is less than the prices received from the sale of their products / services; however, it does not entail a deliberate search (Kirzner 1979, 2019; Yu 2001). Deliberate search involves a commitment of resources (Kirzner 2019) in which the "agents already know enough of the territory that they know what kind of information they want and where to acquire such information" (Yu 2001 51). Yet Tony Fu-Lai Yu (2001) argued that agents search because they are dissatisfied with their current information. This dissatisfaction motivates a search for better knowledge involving the asymmetric knowledge experiences of the entrepreneur (Shane and Venkataraman 2001, Yu 2001). As employees' knowledge of the particulars are distributed across an organization's factors of production, an entrepreneur has an asymmetric knowledge that enables the entrepreneur to assemble these distributed experiences at a total price or cost that is less than their value uses (i.e., prices of the products or services received). Specifically, the task facing the alert entrepreneur is to draw on their asymmetric knowledge experiences in discovering those wage rates that will not only incentivize employees to utilize their knowledge of the particulars, but to also discover a wage rate 
that is less than the prices of their sold products or services. Hence, through this alert discovery of arbitrage opportunities, the entrepreneur engages in a nondeliberate search in which employees' knowledge of the particulars is brought into use by the price system to solve the Hayekian knowledge problem.

\section{Internal Hayekian Knowledge Problem}

Yet in spite of Kirzner's (1979) contributions to solving the Hayekian knowledge problem, the entrepreneur faces a distinct "internal Hayekian knowledge problem" (Elert and Henrekson 2019; Foss 1997). This internal Hayekian knowledge problem involves a use of knowledge in which employees' knowledge of the particulars cannot be centralized under the direction of an entrepreneur's authority (see also Cowen and Parker 1997; Elert and Henrekson 2019; Shane 2000). According to Hayek (1945), employees' knowledge of the particulars cannot be centralized because this centralization requires aggregating an employee's knowledge of the particulars in which differences in their local work conditions and special circumstances would be abstracted away. Due to the distributed nature of an employee's knowledge of the particulars, this knowledge thereby cannot be conveyed to a central authority (Hayek 1945, 524). Since entrepreneurs are also tasked with allocating their firm's factors of production (e.g., Klein 1996; Bylund 2016), this inability to centralize their employee's knowledge of the particulars renders the entrepreneur unable to allocate their factors of production-employees-to their most valued uses. As result, unlike the traditional Hayekian knowledge problem, the internal Hayekian knowledge problem raises a distinct firm-level problem, because the challenges surrounding the centralization of a firm's distributed knowledge impact a firm's internal allocation of resources.

The internal Hayekian knowledge problem is closely tied to Ludwig von Mises's economic calculation problem, and both can be used to elaborate on this firm-level distinction. According to Mises, a firm is tasked with an economic calculation problem of allocating a firm's resources or factors of production that would satisfy the needs of its consumers (Foss and Klein 2010; Klein 1996). This allocation requires that the entrepreneur understand current 
factor prices as well as the anticipated prices of consumer goods sold (Foss and Klein 2010). An understanding of these current factor prices is critical, because in the absence of these factor prices, the entrepreneur cannot allocate their factor inputs into meeting the firm's consumer needs (Klein 1996). Mises has used this economic calculation problem to challenge centrally planned governments, because the absence of property rights over factors of production limits a firm's ability to discover the prices of their factor inputs (Klein 1996). In the absence of these factor prices, socialistic and, more generally speaking, centralized planned organizations, cannot offer an allocation of capital that solves the economic calculation problem (Bylund 2016; Klein 1996; Foss and Klein 2010). The internal Hayekian knowledge problem parallels the criticisms raised by Mises's economic calculation problem. According to Hayek (1945), the distributed nature of an employee's knowledge renders such knowledge unable to be aggregated into a price statistic (Hayek 1945). In the absence of these internal prices, an employee's knowledge of particulars cannot be coordinated into discovering an allocation of resources that will meet the needs of the firm's customers. As a result, like Mises, the internal Hayekian problem underscores that centrally planned organizations face limits in their ability to solve the economic calculation problem.

\section{ENTREPRENEURIAL JUDGMENT}

To address limits in a firm's central authority, an entrepreneur's judgment has been offered as a response to Mises's economic calculation problem (Bylund 2016; Klein 1996). Judgment refers "to the process of businesspeople forming estimates of future events in situations in which the relevant probability distributions are themselves unknown" (Foss, Foss, and Klein 2007, 1896). For instance, judgment can involve the formation of a business plan in which factor inputs are identified and coordinated with the purpose of earning future rents or profits (Foss, Foss, and Klein 2007). This judgment occurs by giving the entrepreneur ownership over the use of a firm's factor inputs (Foss, Foss, and Klein 2007; Foss and Klein, 2010). According to Mises's economic calculation problem, ownership over factor inputs creates an entrepreneurial incentive to reveal their prices such that factors of production can be allocated in 
ways that satisfy future needs or demand expectations (Klein 1996). This is because factor prices are influenced by the varied uses of an input, which gives owners of capital a strong incentive to reveal their factor input's valued uses (see also Bylund 2016; Klein 1996). The challenge, however, is that these valued uses are known only by members who have an intimate or particular understanding of a factor's varied uses (Hayek 1945). Hence, judgment suggests that owners of capital have a strong incentive to encourage their employees to utilize their knowledge of particulars to addressing their firm's economic calculation problem (see also Klein and Foss 2010; Klein 1996). This is consistent with Per Bylund (2016), who noted, "the only basis for making decisions and attempting to identify room for improvement is entrepreneurial judgment: there are no market prices to guide the entrepreneur" (110). This judgment suggests that through ownership the entrepreneur exerts control over the firm's internal allocation of resources that is distinct from those resource allocations determined by market prices (e.g., Foss, Foss, and Klein 2007).

\section{Theory of the Firm: An Austrian Judgment Perspective}

To understand this internal allocation, R. H. Coase's theory of the firm is instructive to Austrian explanations of judgment (see also Bylund 2020; Klein and Foss 2010).In that, while Kirznerian (1979) and Hayekian (1945) explanations would argue that market prices would incentivize employees to utilize their knowledge of the particulars, Coase (1937) had long recognized that there is a transaction cost in determining these relevant prices. Coase (1937) argued that if there are no transaction costs, an employee's knowledge can be readily coordinated through a series of market-based exchanges. These contractual exchanges would do away with the need to transmit any knowledge to a central authority, and thus an organization - as defined by Coase (1937) an authority would cease to exist. The fact, however, remains that authority exchanges exist in all types of organizations, including entrepreneurial ones. The existence of these exchanges suggests that the price system is not a sufficient mechanism to incentivize the use of knowledge within an organization (see also Elert and Henrekson 2019; Shane 2000). This is particularly the case when considering an employee's knowledge 
of the particulars, because such knowledge is tacitly known to the employee. With this tacitness, external prices cannot readily reveal the valued uses of an employee's knowledge of particulars (see also Bylund 2016; Foss and Klein 2010), because there is a transaction cost in organizing this tacit knowledge through a market-based exchange. Thus, according to a Coasian explanation, a firm's existence can be attributed to an entrepreneur's judgment because judgment offers an alternative to market prices in allocating a firm's internal resources (Bylund 2016, 2020).

For instance, Bylund (2020) draws on a Coasian argument to explain a firm's existence. Bylund (2020) attributes a firm's existence to the entrepreneur/manager's ability to "actively directs factors of production instead of the price mechanism" (10). Through an entrepreneur/manager's authority, external market exchanges are internalized in the firm, avoiding the transaction costs of the market (Bylund 2020). These transaction or marketing costs involve costs in determining factor prices and organizing factor inputs. Bylund (2020) argues that a firm exists when the entrepreneur/ manager directs an internal allocation of resources that avoids these marketing costs. Yet, due to limits in bounded rationality, an entrepreneur/manager's internal allocation of resources is subject to diminishing returns. These diminishing returns limit an entrepreneur/manager's ability to replicate the resource allocations of the market. Hence, Bylund (2020) argues that a firm's existence depends on developing an internal allocation that not only avoids marketing costs (MktgCost) but also avoids the relative inefficiency of an entrepreneur/manager's internal allocation $\left(A_{s}\right)$ to a market efficient allocation $\left(A_{e}\right) \cdot{ }^{1}$ By drawing on this marginal analysis, Bylund $(2020)^{2}$ also argues that the entrepreneur/manager can increase the size of their firm's operation when their internal allocation of resources $\left(A_{\mathrm{s}}\right)$ exceeds the difference between the market efficient allocation $\left(A_{e}\right)$ of resources and the market costs associated with this allocation $(M k \operatorname{tg} \operatorname{Cos} t)$.

\footnotetext{
${ }^{1}$ According to Bylund (2020), a firm's existence is explained by a simple rearrangement of his terms where $M k t g$ Cost $>A_{\rho}-A_{s}$.

${ }^{2}$ It should also be noted that Bylund's (2020) work is based on an interpretation of Coase's original insights. This work involves formulizing Coase's theory and this formulization should not be conflated with Coase's original or seminal contributions. An alternative to Coase's theory is offered by Bylund (2016)
} 
Although Bylund (2020) does not directly examine the role of entrepreneurial judgements, an entrepreneur's judgement is implicit in its explanations (see Bylund 2016). Since the entrepreneur/manager plays a "directive" role in the firm's internal allocation of resources (Bylund 2020), an entrepreneur's judgments surrounding the prices of factor inputs can offer an internal allocation of resources $\left(A_{s}\right)$ that avoids Bylund's (2020) marketing costs. For instance, since an entrepreneur's judgment encourages employees to utilize their knowledge of the particulars (see also Foss, Foss, and Klein 2007), such knowledge offers an internal allocation of resources that is not readily known through external market prices. This judgment thereby offers an internal allocation $\left(A_{s}\right)$ that avoids marketing costs and thus impacts a firm's reason to exist. Furthermore, since an entrepreneur's judgment is also subject to limits in bounded rationality, there are diminishing returns to an entrepreneur's judgments. Such diminishing returns can reduce the efficiency of an entrepreneur's internal allocation of resources $\left(A_{s}\right)$ and thus impact the boundary conditions described in Bylund's (2020) marginal analysis.

\section{Entrepreneurial Judgment and a Firm's Internal Organization}

Although the concept of judgment offers important insights for explaining a firm's existence and boundaries (e.g., Bylund 2016, 2020), Foss, Foss, and Klein's (2007) theory of economic organization argues that an entrepreneur's judgment can also impact a firm's internal organization. According to Foss, Foss, and Klein. (2007), judgment involves a leadership role in which a firm's human and capital assets are organized under the direction and control of the entrepreneur. This internal organization involves judgments surrounding the design of a firm's formal and informal communication structures and system of rewards that would secure the control and support of a firm's employees (Cowen and Parker 1997; Foss, Foss, and Klein 2007; Rigtering, Weitzel, and Muehlfeld 2019). This internal organization has been historically described by an authoritarian decision-making structure in which the entrepreneurial leader has direct control and influence over their employees' behaviors (Bylund 2020; Coase 1937; Cowen and Parker 1997). Yet, due to the increasing complexity of markets, modern organizations 
face increasing pressures to organize this internal decision-making structure in ways that best respond to these external changes (Cowen and Parker 1997; Foss, Foss, and Klein 2007; Rigtering, Weitzel, and Muehlfeld 2019). This internal organization involves delegating a leader's decision-making authority to all levels of the firm's decision-making hierarchy (see also Cowen and Parker 1997; Foss, Foss, and Klein 2007; Rigtering et al 2019).

In response to this decentralization of decision tasks, Foss, Foss, and Klein (2007) argue that an entrepreneur's leadership role involves organizing the firm's decision-making authority such that employees are engaged in a "derived judgment" that acts on behalf of the entrepreneur's original judgments (see also Cowen and Parker 1997; Rigtering, Weitzel, and Muehlfeld 2019; Witt, 1998, 1999). An entrepreneur's original judgment, or simply judgment, refers to the "formation and execution of a business idea" (Foss, Foss, and Klein 2007, 1896), such as a firm's mission or goals. A derived judgment involves "utiliz[ing] the knowledge best known to" the employee (Foss, Foss, and Klein 2007, 1894) in responding "to new circumstances or situations that may be unknown to the employer." (Foss, Foss, and Klein 2007, 1894). These derived judgments draw on the employee's knowledge to develop "productive" activities that advance an entrepreneur's mission or judgment (Foss, Foss, and Klein 2007; see also Rigtering, Weitzel, and Muehlfeld 2019). Yet since this derived judgment is predicated on giving employees greater discretionary powers, employees can also draw on their knowledge to advance their personal goals (Foss, Foss, and Klein 2007). An employee's derived judgment can thereby result in "unproductive" activities that undermine the entrepreneur's mission or judgment (Foss, Foss, and Klein 2007). Hence, the challenge surrounding an entrepreneur's judgment is in organizing a decision-making structure in which employees utilize their knowledge to serve the entrepreneur's judgment and not their own (see also Cowen and Parker 1997; Witt, 1998).

For instance, Ulrich Witt's $(1998,1999)$ concept of entrepreneurial leadership reflects this type of judgment. According to Witt (1998), entrepreneurial leadership involves a judgment surrounding an entrepreneur's "imaginations" about the future prospects of a firm's business concept or mission. Such imaginations or judgments are realized by inducing the support of the firm's employees (Witt 
1998). As in Foss, Foss, and Klein (2007), this support operates within a decentralized organizational setting. With this decentralization, there are limits on a leader's bounded rationality that preclude the leader from directly controlling and influencing their employees' behavior. Witt (1998) argues that this decentralization requires a leadership that appeals to the social and psychological aspects of a firm's internal organization (Witt 1998). The social aspects of a firm's internal organization involve instituting a social consensus among employees in order to realize an entrepreneur's imaginations. In addition, while financial renumeration is important to inducing the support of employees, Witt (1998) argues that leadership must also appeal to an employee's psychological motivations. This may involve relating an entrepreneur's imaginations to an employee's personal values. Hence, according to Witt (1998), judgments involve a leadership role of instituting a social and psychological decision-making process that seeks the support of employees. Such judgments are central to an entrepreneur's leadership, because they allow the entrepreneurial leader to utilize their employees' decentralized knowledge experiences in fulfilling the entrepreneur's imaginations or judgments (see also Cowen and Parker, 1997).

\section{ENTREPRENEURIAL EMPOWERMENT}

Yet although the organization of a firm's decentralized experiences is implicit to the internal Hayekian knowledge problem, an entrepreneur's leadership role in empowering employees to address this knowledge problem remains largely undeveloped in theories of economic organization (Cowen and Parker 1997; Foss, Foss, and Klein 2007; Witt 1998). A concept of entrepreneurial empowerment (EE) is proposed. EE appeals to a judgment in which the decision task of the entrepreneurial leader is to institute "structural and psychological" forms of empowerment that encourage employees to draw on their knowledge of the particulars to realize an entrepreneur's mission or judgment. Specifically, since judgment involves an ownership stake, the entrepreneurial leader is defined as an individual who has an ownership stake in their business and/or holds a senior leadership position in the organization (i.e., CEO). With this ownership stake, the entrepreneurial leader has the incentive and decision-making power to institute structural and 
psychological forms of empowerment practices on their employees (see also Cowen and Parker 1997; Witt 1998).

With this characterization of the entrepreneurial leader, EE approaches the internal Hayek knowledge problem not by viewing the entrepreneur as a central planner, but as a collaborator who cultivates a greater sense of autonomy in their employees. In particular, although giving employees greater decision-making autonomy can offer a means to utilize their knowledge of the particulars (e.g., Foss, Foss, and Klein 2007), this decentralization is only a partial solution. As Hayek (1945) described,

\begin{abstract}
We must solve it by some form of decentralization. But this answers only part of our problem. We need decentralization because only thus can we ensure that the knowledge of the particular circumstances of time and place will be promptly used. But the "man on the spot" cannot decide solely on the basis of his limited but intimate knowledge of the facts of his immediate surroundings. There still remains the problem of communicating to him such further information as he needs to fit his decisions into the whole pattern of changes of the larger economic system. (524-25; author's emphasis)
\end{abstract}

In response to this form of decentralization (see also Cowen and Parker 1997; Foss, Foss, and Klein 2007; Rigtering, Weitzel, and Muehlfeld 2019), EE offers a structural and psychological source of empowerment that addresses the "communicative" and "man on the spot" requirements of Hayek's decentralization. Structural empowerment consists of the communicative systems of a firm's internal organization. This communication involves the provision of "opportunities, information and support" that empower employees to realize their latent skills and experiences (Spreitzer 2008 , 55). Psychological empowerment involves an appeal to the "man on the spot's" intrinsic motivations. These intrinsic motivations involve cultivating a psychological state "in which an individual wishes and feels able to shape his or her work role and context" (Spreitzer 1995, 1444).

The structural and psychological components of EE, it is argued, solve the internal Hayekian knowledge problem by empowering employees to utilize their knowledge of the particulars in addressing the unique or circumstantial challenges of their job tasks. Yet, as employee can utilize their knowledge for their own benefit 
(Foss, Foss, and Klein 2007), the solution to the internal Hayekian knowledge problem also requires that the entrepreneurial leader empower employees to utilize their knowledge of particulars in ways that realize an entrepreneur's mission or judgment. In addition to examining the individual components of the EE concepts-structural empowerment and psychological empowerment-this study argues that an examination of their joint impact can empower employees to utilize their knowledge of the particulars to advance an entrepreneur's mission or judgment. In this fashion, the concept of EE offers a distinct firm-level solution to the internal Hayekian problem. To develop this argument, each of the structural and psychological components of the EE concept are first examined.

\section{Structural Empowerment (SE)}

Based on a social structural perspective, structural empowerment (SE) is defined by a "sharing power (i.e., formal authority or control over organizational resources (Conger and Kanungo 1988)) through the delegation of responsibility throughout the organizational chain of command" (Spreitzer 2008, 55). To institute this redistribution of authority, structural empowerment (SE) consists of practices that make efforts to develop in employees a greater: 1) autonomy to develop goals, a system of rewards, work procedures, and responsibilities in regard to employees' assigned job tasks, 2) transparency of information where strategic goals and direction are communicated in ways relevant to their job performance, and 3) training practices that build their knowledge, skill, and ability to perform their assigned job tasks well (Spreitzer 2008).

The goal of the empowered entrepreneur is to develop SE practices that provide employees with the "opportunity, information, support, and resources" (Spreitzer 2008 55) to fully realize their latent skills and experiences in addressing the changing circumstances of their job (Spreitzer 2008). An entrepreneur can provide opportunities by developing resource forums and centers that promote the sharing of ideas among employees (Hargadon and Sutton 1997). For instance, in their study of the product design firm IDEO, Hargadon and Suttons (1997) pointed out that IDEO created a resource forum that pooled the design solutions used in previous projects. Engineers could draw on this pool to solve the 
current problems they faced in their job tasks. Entrepreneurs can also provide financial support to promote the development of new product ideas. Companies such as Google have provided millions in seed capital to help commercialize products developed by their project teams (Gagne and Deci 2013). Lastly, the entrepreneur can promote a sharing of information, for example through their organization's policies on risk taking. Jeff Bezos and Elon Musk recognize that their organizations' success rests on a policy that failure is a necessary part of the innovation process. This policy of failure can promote greater risk taking in employees and thus promote a greater willingness to experiment with new ideas (Henao-Zapata and Peirỏ 2018).

By providing employees with such opportunities, information, and support, SE practices offer an important communicative structure that demonstrates an entrepreneur's commitment to an employee's autonomy (see also Argyris 1998). Leaders need to communicate to their employees that they have made a personal commitment to empowering them (see also Argyris 1998; Bendahan et al. 2015). Developing this commitment is important, because leaders can engage in empowerment practices with politically correct motivations and not with a genuine commitment in promoting the autonomy of their employees (Argyris 1998). A communicative structure involving the provision of opportunities, information, and support signals a leader's commitment to empowering their employees and thus assures employees that their leader's empowerment efforts are genuine.

Exhibiting this genuine commitment, this communicative structure increases an employee's willingness to exploit their knowledge of the particulars in that it reduces an employee's fear that the use of their knowledge of the particulars will threaten the power and authority of the entrepreneur. For instance, studies find that leaders face difficulties giving up their positions of authority (Argyris 1998; Bendahan et al. 2015). This difficulty arises, because authority offers leaders the power to influence their subordinates in ways that advance a leader's self-interest (Bendahan et al. 2015; Lubit 2002; Schyns and Schilling 2013). Hence, by providing employees the opportunities, information, and support to more fully utilize their knowledge, an entrepreneur not only demonstrates a clear commitment to relinquishing their control over their employees 
but also places trust in employees to utilize their knowledge of the particulars to advance their job task. This commitment as a result reduces the entrepreneur's potential for retaliatory action and reduces an employee's fear that utilizing their knowledge of particulars will threaten the entrepreneur's authority (e.g. Bendahan et al. 2015; Lubit 2002; Schyns and Schilling 2013). This is consistent with empowerment studies that find that employees are hesitant to engage in greater decision-making autonomy because they fear the repercussions this may have for a leader's authority (Spreitzer 1996). Therefore, in order to empower employees, their leaders must give their commitment to this, because in its absence employees do not want to be held accountable for decisions that are not supported by their leaders. SE offers a communicative structure that alleviates such concerns, because the provision of opportunities, information and support signals an entrepreneur's commitment to empowering employees to make decisions.

Proposition 1: SE involving the provision of opportunities, information, and support positively influences an employee to utilize their knowledge of the particulars in their job tasks.

\section{Psychological Empowerment (PE)}

Unlike the communicative aspects of SE, PE appeals to an empowerment that is experienced by the employees themselves (see also Spreitzer 2008). Psychological empowerment (PE) is defined as a "psychological state of a subordinate [i.e., employee] perceiving four dimensions of meaningfulness, competence self-determination and impact, which is affected by empowering behaviours of the supervisor [i.e., entrepreneur]" (Lee and Koh 2001, 686). Each of these psychological states is described as follows:

Meaning involves a fit between the needs of one's work role and one's beliefs, values and behaviours....Competence refers to self-efficacy specific to one's work, or a belief in one's capability to perform work activities with skill....Self-determination is a sense of choice in initiating and regulating one's actions....It reflects a sense of autonomy or choice over the initiation and continuation of work behaviour and processes (e.g., making decisions about work methods, pace, and effort). Impact is the degree to which one can influence strategic, administrative, or operating outcomes at work. (Spreitzer 2008, 57) 
Studies have found that meaning, competence, self-determination, and impact increase an employer's ability to achieve the objectives and challenges of their job (Lee and Koh 2001; Spreitzer 2008). For instance, an employee who finds meaning in their job develops greater motivation in fulfilling the requirements of their job (Henao-Zapata and Peiro 2018). Furthermore, competence or self-efficacy has been associated with improvements in an employee's productivity (Henao-Zapata and Peirò 2018; Spreitzer 1996, 2008). Self-determination in which the employee takes on greater personal responsibilities in defining their job goals has been found to improve an employee's goal achievement (Eva et al. 2019, Henao-Zapata and Peirỏ 2018; Spreitzer 1996, 2008). Lastly, impact has been found to increase an employee's feelings of control over the workplace and promotes a greater commitment to pursuing organizational goals (Spreitzer 2008).

Since leadership is central to the empowerment of employees (Argyris 1998; Lee and 2001; Spreitzer 2008), the goal of the entrepreneur is to PE an employees' sense of meaning, competence, self-determination, and impact in their jobs. This PE involves developing a vision that provides a sense of meaning and purpose to employees. For instance, Truett Cathy, the founder of the immensely successful Chick-fil-A restaurants, developed a vision based on Christian principles in which the glorification of God involved the provision of "second to none" service to his customers. This vision deeply resonated with the personal beliefs of his employees, and this greater sense of meaning and purpose has resulted in a commitment to service that is unrivalled in the food industry (Kruse 2015; Petrone 2014). An entrepreneur can promote self-determination by offering their employees the freedom to explore their personal talents and skills. Companies such as 3M and Google allow their employees to use up to 15 percent of their time to pursue projects of their own choice (Govindarajan and Srinivas 2013). Empowerment studies find that this self-determination can increase an employee's sense of competence that they have the skills and experiences necessary to complete their jobs (Spreitzer 2008). Lastly, entrepreneurs who believe that their products and services have an impact on society can encourage their employees to develop job tasks in realizing such impacts. For instance, Toyota has made a commitment to producing cars that meet its environmental 
sustainability goals. To realize such goals, Toyota's engineering specialists developed a solvent to clean the robots used in painting vehicle bumpers. The use of hazardous chemicals and water was significantly reduced as well as the number of defective bumpers. ${ }^{3}$

By engaging in such forms of $\mathrm{PE}$, entrepreneurs will not only develop a greater sense of meaning, competence, self-determination, and impact in their employees, but employees will also be more likely to utilize their knowledge of the particulars in ways not recognized by Hayek (1945). Hayek (1945) writes that "every individual has some advantage over all others in that he possesses unique information of which beneficial use might be made, but of which use can be made only if the decisions depending on it are left to him or are made with his active cooperation" (521-22). Austrians (Cowen and Parker 1997; Hayek 1945; Kirzner 1979, Foss, Foss, and Klein 2007) would argue that an extrinsic reward system would incentivize employees to engage in this active cooperation, to utilize their knowledge of the particulars. Yet various studies find that financial or extrinsic rewards (i.e., wage rates) can undermine an individual's intrinsic motivation (Argyris 1998; Judge et al. 2010; Kuvaas et al. 2017; Ryan and Deci 2000). Judge et al. $(2010,158)$ explains

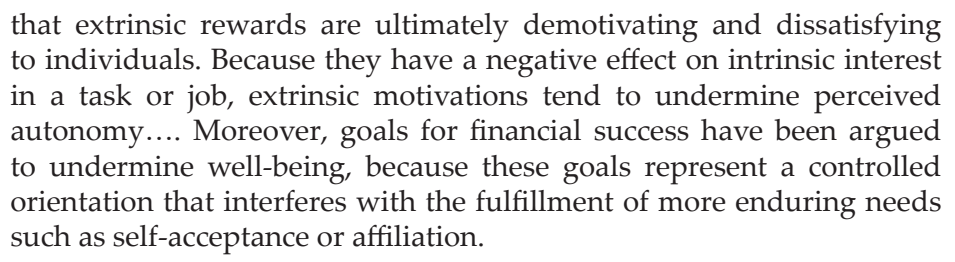

Since PE involves an appeal to an employee's intrinsic motivations, the use of financial, or extrinsic, rewards cannot psychologically motivate an employee to utilize their knowledge of the particulars. The reason is that financial rewards incentivize employees on the basis of achieving performance goals set by their supervisors and not on the basis of goals that advance their personal long-term growth (Judge et al. 2010). Stated differently, extrinsic, financial rewards only incentivize employees to take on initiatives when financial rewards are increased (Argyris 1998; Judge et al. 2010) and thus tend to

\footnotetext{
${ }^{3}$ See https://www.toyota.com/usa/environment/.
} 
undermine an individual's autonomy to fulfill their high-order needs. In contrast to financial rewards, studies have shown that intrinsic motivations are positively related to greater levels of employee persistence and proactiveness (Judge et al. 2010; Kuvaas et al. 2017) and a greater ability to internalize the specific conditions of their work climate (Gagne and Deci 2005). These findings suggest that a PE employee will utilize their knowledge of the particulars in their job task because this knowledge offers them a greater sense of control in their work and the ability to proactively shape their tasks. This increased autonomy allows them to perform their jobs in ways that advance their personal goals and identities. Hence, PE increases an employee's use of their knowledge of the particulars by empowering them to realize their higher-order or self-actualizing needs in ways that cannot be realized by the extrinsic financial rewards of Hayek (1945; see also Spreitzer 2008).

Proposition 2: a PE involving the development of a sense of meaning, competence, self-determination, and impact increases employees' intrinsic motivation to utilize their knowledge of the particulars in their job tasks.

\section{DECENTRALIZATION BENEFITS OF ENTREPRENEURIAL EMPOWERMENT}

By utilizing an employee's knowledge of the particulars, SE and PE not only offer a means to solve the internal Hayekian knowledge problem, but also offer opportunities to exploit the benefits of decentralization. Austrian economists recognize that decentralization introduces intrafirm learning opportunities that increase an organization's ability to adapt to and innovate in changing market conditions (Elert and Henrekson 2019; Foss, Foss, and Klein 2007; Henao-Zapata and Peiro 2018; Rigtering, Weitzel, and Muehlfeld 2019). These benefits of decentralization stem from the greater autonomy given to an organization's subunits to engage in local problem-solving behaviors (Cowen and Parker 1997; Kollman, Miller, and Page 2000; Richardson et al. 2002; Rigtering, Weitzel, and Muehlfeld 2019). For instance, by offering employees greater autonomy in their decision-making, employees can draw on their day to day operational experiences to adapt to the problems faced in their job tasks. Furthermore, this greater autonomy comes with a 
lower resistance to change and thus increases employees' freedom to pursue new ideas and innovations (Henao-Zapata and Peiro 2018; Rigtering, Weitzel, and Muehlfeld 2019). Hence, as structural and psychological empowerment offer employees a greater decision autonomy, these different forms of empowerment enable employees to exploit the adaptive and innovative benefits of decentralization.

Yet since the task of the entrepreneurial leader is to empower employees in ways that realize the entrepreneur's mission or judgment, the structural and psychological components of EE cannot individually accomplish this leadership task. This is because the structural and psychological components operate at different levels of analysis in which neither considers the influences of the other (Siebert, Silver, and Randolph 2004). Empowerment studies have argued that a joint consideration of these components is needed because a firm's internal communication structure has been shown to influence an employee psychological motivations (Siebert, Silver, and Randolph 2004). In the context of entrepreneurial leadership, a leader who jointly leverages the structural and psychological components of the EE concept not only empowers their employees to exploit the adaptive and innovative benefits of decentralization but can also empower employees to utilize their knowledge of particulars to advance an entrepreneur's judgment or mission.

\section{Bounded Autonomy}

To explain this aspect of entrepreneurial leadership, EE exploits the adaptive benefits of decentralization by leveraging the relationship between a firm's "bounded autonomy" and an employee's "self-determination" (Siebert, Silver, and Randolph 2004; Spreitzer 2008). Bounded autonomy refers to the structural empowerment aspects of EE and is defined by "organizational structures and practices that encourage autonomous action, including the development of a clear vision, and clarity regarding goals, work procedures, and areas of responsibility" (Seibert, Silver, and Randolph 2004, 333; see also Spreitzer 1996). In the Austrian economics literature, this bounded autonomy has been described as a "nested hierarchy" (Foss, Foss, and Klein 2007, 1897) or "polyarchy" (Cowen and Parker 1997, 59). Common to these descriptions is that the firm is organized around a number of decentralized / partly autonomous units, each of which 
is delegated a decision authority that operates within the context and constraints of a greater decision-making authority (Cowen and Parker 1997; Foss, Foss, and Klein 2007; Witt 1998).

Although a firm's bounded autonomy is organized in a fashion similar to other studies or economic organization (Cowen and Parker 1997; Foss, Foss, and Klein 2007; Rigtering, Weitzel, and Muehlfeld 2019; Witt, 1998), this study adds that the depth / width of this bounded autonomy is influenced by limits in entrepreneurs' judgment. Due to limits on bounded rationality, transaction cost explanations would argue that an entrepreneur's judgment faces increasing costs in coordinating an increasing specialization of tasks within its decision hierarchy. The depth of an organization's bounded autonomy is influenced by the extent to which these specialized tasks can be vertically integrated within the bounded autonomy (see also Bylund, 2016). With limits on an entrepreneur's judgement, entrepreneurial leaders face increasing difficulties in understanding the specialized decisions made by lower or deeper members of its decision hierarchy because these employees' tasks are highly specialized to the unique circumstances and challenges of their local work environment. As result, an entrepreneur's efforts to institute a bounded autonomy are subject to diminishing returns that limit the depth of specialized activities that can be integrated into this bounded autonomy. Furthermore, limits in an entrepreneur's judgment also impact the width or scope of activities in a firm's bounded autonomy. The width or scope of a bounded autonomy consists of the diversity of specialized activities in a firm's decision hierarchy. Bylund (2016) argues that this diversity of specialized activities can exhibit interdependencies or synergies that are difficult for the entrepreneur to know. The width of scope of these experimented activities is thus limited by an entrepreneur's ability to discover the interdependencies or synergies among them. Hence, as an entrepreneur's EE is impacted by their judgment, an entrepreneur's efforts to institute a bounded autonomy are subject to cognitive limitations that restrict the depth / width of this bounded autonomy.

By recognizing such limits in an entrepreneur's structural empowerment efforts, a bounded autonomy is distinct from other decentralized forms of organization, such as Oliver E. Williamson's (1975) M-form organizational structure. Williamson's (1975) M-form organization emphasizes a highly diversified knowledge structure 
in which units are unrelated to the activities of others. With this autonomy, employees in each unit compete against others for corporate funds. While such competition offers a means to replicate the external market process, unit goals are prioritized over corporate goals (Cowen and Parker 1997). In contrast, the units in a bounded autonomy are guided and directed by the limits of an entrepreneur's judgment. In order to conserve an entrepreneur's bounded rationality, the entrepreneurial leader institutes a bounded autonomy in which the depth and width of unit activities are limited to those activities that are related to an entrepreneur's mission or judgment. Hence, consistent with Cowen and Parker (1997), limits in an entrepreneur's judgment result in a bounded autonomy in which the depth / width of a unit's activities exhibit a coherence or relatedness that is absent from Williamson's M-form structure.

\section{Bounded Autonomy and Self-Determination}

Under a bounded autonomy, employees engage in a self-determination that exploits the adaptive benefits of decentralization in ways consistent with an entrepreneur's mission or judgment. Specifically, bounded autonomy reduces the ambiguities surrounding the expectations and scope of an employee's decision-making authority (Spreitzer 1996). This reduction of ambiguity is important, because "if people do not know the extent of their authority and what is expected of them, they will hesitate to act (i.e. lack of self-determination) and thus feel unable to make a difference (i.e. lack impact)" (Spreitzer 1996, 487). This reduction of ambiguity offers employees a clear delineation of their decision-making authority, promoting a greater sense of self-determination that avoids the resistance to change typically found in organizational bureaucracies (Spreitzer 1996) by giving employees greater authority to draw on their knowledge of the particulars to address the challenges and expectations of their jobs. Studies find that such self-determination can increase an employee's resiliency in their decision-making and promote a greater resourcefulness to seek local resources and experiences (Henao-Zapata and Peiro 2018; Spreitzer 1996). This resiliency and resourcefulness suggest that employees will draw on their knowledge of the particulars to gain an intimate understanding of their local work conditions. 
This localized understanding in turn increases an employee's ability to adapt to the changing circumstances of their job. Unlike the unproductive behaviours described by Foss et al. (2007), an employee's self-determination is constrained by a firm's bounded autonomy. That is, a bounded autonomy offers a clear delineation of an employee's delegated decision-making authority in which their self-determination is limited to their local conditions.

For instance, the joint influences of bounded autonomy and self-determination can be explained in terms of Koch Industries' "market-based management" strategy (Cowen and Parker 1996; see also Klein 1996). This management strategy involves communicating the corporate mission to each business unit and delegating a decision-making authority to each unit in support of this corporate mission. This delegated decision-making offers a type of "bounded autonomy" in which units are given discretion to determine unit-level missions that guide their employees to make daily decisions that support the corporate mission (Cowen and Parker 1997). With respect to the self-determinative aspects of psychological empowerment, Koch's market-based management also involves adopting a matrix management structure in which employees report to the senior managers of different units. With this matrix management, employees are "ultimately accountable to the consumer of the firm's products and to the firm's mission rather than to some specific individual known as a "boss" (Cowen and Parker 1997, 50-51). While we cannot directly assess the psychological aspects of an employee's self-determination, Koch's matrix structure offers a means for employees to assert their self-determination in responding to the needs of the firm's customers. Furthermore, Koch Industries also offers compensation that rewards employees for developing products and services that advance the firm's mission. These resources provide opportunities that affirm an employee's self-determination. As a result, by jointly leveraging the bounded autonomous and self-determinative aspects of $\mathrm{EE}$, these empowerment practices enable employees to exploit the adaptive benefits of decentralization in ways that also advance the entrepreneur's mission or judgment (see also Cowen and Parker 1997).

Proposition 3: entrepreneurial empowerment involving a SE practice of bounded autonomy positively influences an employee's 
PE by developing a self-determination that adapts to an entrepreneur's mission or judgments.

\section{Broad Sharing of Information and Competence}

In addition, EE offers a structural and psychological empowerment that exploits the decentralized benefits of innovation. Specifically, a SE policy involving a broad sharing of information can psychologically empower employees to institute new ideas in their job tasks by promoting a sense of competence. This broad sharing of information involves sharing an organization's strategy to all members of its decision hierarchy (Spreitzer 1996). For instance, Kellogg's CEO, Carlos Gutierrez, instituted a value-added strategy that differentiated Kellogg's products from an increasingly competitive cereal market. Mr. Gutierrez was successful in implementing this value-added strategy, because he was able to relate this differentiation strategy to the specific job demands and goals of every employee in his organization (Boyle 2004). Empowerment studies find that this broad sharing of information increases an employee's sense of meaning and purpose, because employees can see the "big picture" and gain a better understanding of how their job fits within their organization's broader vision or mission (Siebert, Silver, and Randolph 2004; Spreitzer 1996). Furthermore, studies find that this greater sense of meaning and purpose can increase an employee's feelings of competence (Gagne and Deci 2005; Siebert, Silver, and Randolph 2004; Spreitzer 1996). This competence is important to instituting new ideas and innovations, because it increases employees' perception that their implemented ideas will succeed and will have a meaningful impact on their organization's future goals (Gagne and Deci 2005; Henao-Zapata and Peirỏ 2018; Seibert et al. 2004).

As entrepreneurs are often admired for their vision, an EE involving a broad sharing of information psychologically empowers an employee's competence to engage in innovations that realize this vision. Specifically, a broad sharing of an entrepreneur's vision offers employees a greater context in which to understand how their knowledge of the particulars can help realize an entrepreneur's vision. This communication is important, because an employee who fails to understand how their knowledge of the particulars fits 
within the entrepreneur's vision can create coordination problems (Witt 1998). Each employee will seek to utilize their knowledge of the particulars without considering their impact on others. As a result, such autonomous decision-making introduces conflicts in implementing innovations that would realize an entrepreneur's vision (see also Foss, Foss, and Klein 2007). In order to avoid such conflicts, employees must develop a shared understanding of the entrepreneur's vision (Spreitzer 1996; Witt 1998). This shared understanding is consistent with the communicative aspects of Hayek's (1945) decentralization which posits that an employee's knowledge of the particulars need to be understood within the context of a larger information system (see also Witt 1998). However, since Hayek (1945) relies on the price system to communicate the goals of this larger system, he does not consider those communication systems that appeal to an employee's intrinsic motivations. EE addresses this shortcoming. An EE involving the broad sharing of an entrepreneur's vision with all members of their organization (such as Gutierrez's strategy at Kellogg's), psychologically empowers an employee's feeling of competence. This empowerment occurs, because a shared understanding aligns an employee's knowledge of the particulars with their entrepreneur's vision (Witt 1998) and thus increases an employee's feelings of competence-that their knowledge of the particulars can have an impact in realizing the entrepreneur's vision. This competence energizes an employee's creativity to utilize their knowledge of particulars to develop new ideas in their jobs.

For instance, 3M started a new product that started with a complaint in their customer care division. The employee sought a solution by conducting his own research and then recontacted the customer to see if the solution was a suitable remedy (Rubinson 2009). This is consistent with studies' finding that empowered employees tend to engage in greater creativity and innovation (Gagne and Deci 2005; Henao-Zapata and Peirỏ 2018; Kuvaas et al. 2017; Zhang and Bartol 2010). However, unlike these studies, which focus on the psychological aspects of empowerment, this study argues that a broad sharing of entrepreneur's visions empowers employees competence to utilize their knowledge of the particulars to discover novel solutions that would realize an entrepreneur's vision. This is consistent with J. P. C. Rigtering, G. U. Weitzel, and K. Muehlfeld 
(2019), who argue that lower-level managers and employees draw on their domain-specific knowledge to implement new business ideas. Hence, they argue, the task of corporate leaders is to "contextually frame" these lower-level innovative efforts to align with the corporate vision. This study argues that a SE practice of broad information sharing and its influence on an employee's competence can contribute to a contextual framing in which the entrepreneur is able to exploit the decentralized benefits of innovation.

Proposition 4: entrepreneurial empowerment involving a SE practice of broad information sharing positively influences an employee's PE by developing their competence to innovate in activities that advance an entrepreneur's mission or judgment.

\section{DISCUSSIONS AND CONCLUSIONS}

As entrepreneurs' success is often attributed to their ability to identify unnoticed market opportunities, the discovery of opportunities within a firm's internal organization remains largely underexamined in Austrian economics and mainstream entrepreneurship research (see Alvarez, Barney, and Anderson 2013). Yet leadership research has widely recognized that employees are central to an organization's success and thus the task of a leader is to empower their employees to realize this success. This distinction was recognized earlier by Chester I. Barnard's (1938) seminal work on leadership. He argued that the quintessential task of a leader is to communicate and empower a common purpose to their employees. A concept of entrepreneurial empowerment has been developed in which opportunities for employee empowerment are used to solve an internal Hayekian knowledge problem. In this solution to the internal Hayekian problem, the entrepreneur's task as a leader is to structurally and psychological empower their employees in order to unleash their latent potential. EE's structural and psychological dimensions motivate employees to use their knowledge of the particulars to discover the adaptive and innovative benefits of decentralization. EE has three implications for Austrian economics and entrepreneurship research.

First, according to Austrian economic explanations, adaptation and innovation are largely explained in terms of market-level 
processes. As result, an organization's adaptive and innovative processes remain generally understood as a "black box" (Kirzner 2019). EE offers a direction for Austrian economists to "open" up this black box in which a venture's ability to adapt and innovate is attributed to the structural and psychological aspects of the EE concept. EE introduces an adaptive and innovative process that is endogenous to an employee's knowledge of the particulars. This endogenous process underscores that although the success of a venture is widely attributed to its entrepreneur's inspirational ideas, a venture's success can also come from those involved in executing these ideas. This is because employees have the most familiar understandings of the challenges surrounding the implementation of their leader's ideas. More broadly speaking, this knowledge of the particulars offers employees a unique position to adapt and innovate activities that reconcile the challenges of their job tasks with the ideas and goals of the entrepreneur. The utilization of this knowledge opens up the black box of Austrian entrepreneurship, in which an organization's adaptation and innovation is explained by a decentralized process that cannot be centralized by an entrepreneur's leadership (see also Shane 2000).

More fundamentally, EE's utilization of an employee's knowledge of the particulars offers a decentralization that appeals to Mises's open-ended view of entrepreneurship (Salerno 1993). By solving the internal Hayekian problem, EE offers an economic calculation in which the employee's knowledge of the particulars is used in determining an allocation of internal resources that meets the needs of a firm's consumers. Since consumer needs will continually evolve, EE's solution to the internal Hayekian problem offers an economic calculation that evolves with the changing needs of the consumer. Consistent with Mises, EE will result in an economic calculation in which this changing allocation of internal resources may not converge toward an equilibrium outcome (see also Salerno 1993). EE thereby offers an alternative to alert explanations of the market process.

Second and relatedly, since the concept of EE has a distinctly proactive orientation, EE introduces a "deliberateness" not found in alert entrepreneurial explanations (Kirzner 2019). Unlike with Kirzner (2019), the structural and psychological dimensions of EE involve a search that requires a deliberate commitment of an 
entrepreneur's time and efforts. Structural empowerment requires that the entrepreneur institute practices that provide employees the opportunity, information and support to realize their latent potential. As these policies involve redistributing the power in an organization's hierarchy, supervisory members of this hierarchy are likely to resist such policies, because they undermine their position of power and influence (Argyris 1998; Bendahan et al. 2015). Hence, an entrepreneur who institutes such SE policies is likely to expend considerable time and effort in overcoming this resistance. ${ }^{4}$ With this commitment of effort, EE introduces a deliberateness that is particularly relevant to addressing recent debates surrounding an entrepreneur's claims to the wealth creation process. For instance, a NY representative, Alexandria Ocasio-Cortez, argued that wealthy business owners did not deserve their wealth because they "sat on couches, while thousands were paid modern day slave wages." EE argues that due to the commitment of resources required by the structural and psychological empowerment process, entrepreneurs have a direct claim to such wealth. Stated differently, EE argues for a Friedman system of ethics (see also Bylund 2019, Kirzner 2019) that justifies an entrepreneur's wealth on the basis that they have contributed resources in empowering their factors of production (i.e., employees). Hence unlike Kirzner's (2019) rejection of Friedman's system of ethics, EE argues that entrepreneurs have a legitimate moral claim to the wealth creation process, because this wealth creation is based on an entrepreneur developing a deliberate relationship to their factors of productions (see also Bylund 2016).

Third and lastly, the concept of EE offers a type of judgment that is important to explaining a firm's internal organization. EE appeals to a judement that is not principally concerned with developing an internal allocation of resources that reduces the transactions cost of the market. Instead, EE appeals to a judgment in which the task of the entrepreneurial leader is to organize a firm's internal decision-making structure in which employees utilize their knowledge of particulars

\footnotetext{
${ }^{4} \mathrm{~A}$ reviewer has noted that once an entrepreneur has instituted such structural and psychological forms of empowerment this resistance to change will not likely persist. That is, the ultimate goal of EE is to empower employees to act in accordance to an entrepreneur's mission or judgment. Hence little resistance by employees will be expected once the individual and joint efforts of EE are instituted by the entrepreneur.
} 
to advance their entrepreneur's judgment. In addition, entrepreneurs are often viewed as visionary leaders. But entrepreneurs have a leadership responsibility to not only articulate a compelling vision to their employees, but also to empower their employees to realize this vision. The concept of EE offers a type of judgement in realizing entrepreneurial visions. This judgment involves efforts to organize a firm's internal communication structure and to provide appropriate psychological motivations that empower employees to realize their entrepreneur's vision. The implication of this wealth creation process is that EE favors a more creative explanation of entrepreneurial opportunities (Alvarez and Busenitz 2001) in which opportunities are brought into existence by the empowerment efforts of the entrepreneur. EE, however, does not imply a rejection of the price arbitrage opportunities of alert entrepreneurship, because alert entrepreneurship and EE are concerned with solving different knowledge problems. EE emphasizes a distinctly firm-level approach to solving the internal Hayekian problem. This firm-level approach argues that an employee's inherent potential cannot be fully realized by the external price system. In contrast, alertness emphasizes the discovery of price arbitrage opportunities at the market level and therefore relies on prices that cannot reveal an employee's latent potential. An important direction for Austrian economics research is to examine both forms of entrepreneurship, because they address different aspects of the entrepreneurial discovery process.

\section{REFERENCES}

Alvarez, Sharon A., and Lowell W. Busenitz. 2001. “The Entrepreneurship of Resource-ased Theory." Journal of Management 27, no. 6: 755-75.

Alvarez, Sharon A., Jay B. Barney, and Philip Anderson. 2013. "Forming and Exploiting Opportunities: The Implications of Discovery and Creation Processes for Entrepreneurial and Organizational Research." Organization Science 24, no. 1: 301-17.

Argyris, Chris. 1998. "Empowerment: The Emperor's New Clothes." Harvard Business Review, May-June 1998, 98-105.

Ashford, Susan J., and Sim B. Sitkin. 2019. "From Problems to Progress: A Dialogue on Prevailing Issues in Leadership Research." Leadership Quarterly 30, no. 4: 454-60. 
Barnard, Chester I. 1938. The Functions of the Executive. Cambridge, Mass.: Harvard University Press.

Bendahan, Samuel, Christian Zehnder, François P. Pralong, and John Antonakis. 2015. "Leader Corruption Depends on Power and Testosterone." Leadership Quarterly 26, no. 2: 101-22.

Boyle, Matthew. 2004. “The Man Who Fixed Kellogg Stale Offerings. Soggy Profits. Carlos Gutierrez Inherited Both When He Got the Top Job at the Cereal Giant. But Look at It Now." Fortune, Sept. 6, 2004. https://money. cnn.com/magazines/fortune/fortune_archive/2004/09/06/380333/ index.htm

Bylund, Per L. 2016. "Financing, Ownership, and Boundaries of the Firm." Pp. 107-120 in The Problem of Production, a New Theory of the Firm, ed. Per L. Bylund. New York: Routledge.

_ 2019. "The Austrian Free Enterprise Ethic: A Mengerian Comment on Kirzner (2019)." Review of Austrian Economics. https://doi.org/10.1007/ s11138-019-00496-3.

— Forthcoming. "The Firm vs. The Market: Dehomogenizing the Transaction Cost Theories of Coase and Williamson." Strategic Management Review.

Coase, R. H. 1937. “The Nature of the Firm.” Economica 4, no. 16: 386-405.

Conger, Jay A., and Rabindra N. Kanungo. 1988. "The Empowerment Process: Integrating Theory and Practice." Academy of Management Review 13, no. 3: 471-82.

Cowen, Tyler, and David Parker. 1997. Markets in the Firm: A Market-Process Approach to Management. London: Institute of Economic Affairs.

Elert, Niklas, and Magnus Henrekson. 2019. "The Collaborative Innovation Bloc: A New Mission for Austrian Economics." Review of Austrian Economics 32, no. 4: 295-320.

Eva, Nathan, Mulyadi Robin, Sen Sendjaya, Dirk van Dierendonck, and Robert C. Liden. 2019. "Servant Leadership: A Systematic Review and Call for Future Research." Leadership Quarterly 30, no. 1: 111-32.

FastCo Works. 2019. "Meaningful Innovation Driven by Culture." Fast Company, Aug. 6, 2019. https://www.fastcompany.com/90377786/ meaningful-innovation-driven-by-culture. 
Foss, Nicolai J. 1997. "Austrian Economics and the Theory of the Firm." Working paper, Department of Industrial Economics and Strategy 97-3, March 18, 2020. https://openarchive.cbs.dk/bitstream/ handle/10398/7210/wp97-3.pdf?sequence=1.

Foss, Nicolai J., and Peter G. Klein. 2012. Organizing Entrepreneurial Judgement a New Approach of the Firm. New York: Cambridge University Press.

Foss, Nicolai J., and Peter G. Klein. 2010. "Alertness, Action, and the Antecedents of Entrepreneurship." Journal of Private Enterprise, 25, no. 2: 145-64.

— 2016. "Entrepreneurial Discovery or Creation? In Search of the Middle Ground." Academy of Management Review 42, no. 4: 733-36.

Foss, Kirsten, Nicolai J. Foss, and Peter G. Klein. 2007. “Original and Derived Judgement: An Entrepreneurial Theory of Economic Organization." Organization Studies 28, no. 12: 1893-1912.

Gagné, Marylène, and Edward L. Deci. 2005. "Self-determination Theory and Work Motivation." Journal of Organizational Behavior 26, no. 4: 331-62.

Govindarajan, Vijay, and Srikanth Srinivas. 2013. “The Innovation Mindset in Action: 3M Corporation." Harvard Business Review, Aug. 6, 2013. https://hbr.org/2013/08/the-innovation-mindset-in-acti-3.

Hargadon, Andrew, and Robert I. Sutton. 1997. "Technology Brokering and Innovation in a Product Development Firm." Administrative Science Quarterly 42 no. 4: 716-49

Hayek, F. A. 1945. "The Use of Knowledge in Society." American Economic Review 35, no. 4: 519-30.

- 1952. Counter-revolution of Science: Studies on the Abuse of Reason. Glencoe, Ill.: Free Press.

Henao-Zapata, Daniel, and José M. Peiró. 2018. “The Importance of Empowerment in Entrepreneurship." Pp. 185-206 in Inside the Mind of the Entrepreneur: Cognition, Personality Traits, Intention, and Gender Behavior, ed. Ana Tur Porcar and and Domingo Ribeiro Soriano. Cham, Switzerland: Springer.

Judge, Timothy A., Ronald F. Piccolo, Nathan P. Podsakoff, John C. Shaw, and Bruce L. Rich. 2010. "The Relationship between Pay and Job Satisfaction: A Meta-Analysis of the Literature." Journal of Vocational Behavior 77: 157-67. 
Kirzner, Israel M. 1979. Perception, Opportunity, and Profit: Studies in the Theory of Entrepreneurship. Chicago: University of Chicago Press.

_. 2009. "The Alert and Creative Entrepreneur: A Clarification." Small Business Economics 32, no. 2: 145-52.

— 2019. "The Ethics of Pure Entrepreneurship: An Austrian Economics Perspective." Review of Austrian Economics 32, no. 2: 89-99.

Klein, Peter G. 1996. "Economic Calculation and the Limits of Organization." Review of Austrian Economics 9, no. 2: 3-28.

Klein, Peter G., and Per L. Bylund. 2014. "The Place of Austrian Economics in Contemporary Entrepreneurship Research." Review of Austrian Economics 27, no. 3: 259-79.

Kollman, Ken, John H. Miller, and Scott E. Page. 2000. "Decentralization and the Search for Policy Solution." Journal of Law, Economics, and Organization 16 no. 1: 102-28.

Kruse, Kevin.2015. "How Chick-fil-A Created aCulture ThatLasts." Forbes, Dec. 8, 2020. https://www.forbes.com/sites/kevinkruse/2015/12/08/ how-chick-fil-a-created-a-culture-that-lasts/\#e0458613602e.

Kuvaas, Bård, Robert Buch, Antoinette Weibel, Anders Dysvik, and Christina G. L. Nerstad. 2017. “Do Intrinsic and Extrinsic Motivation Relate Differently to Employee Outcomes?" Journal of Economic Psychology 61: 244-258.

Lee, Allan, Sara Willis, and Amy Wei Tian. 2018. “When Empowering Employees Works, and When It Doesn't." Harvard Business Review, Mar. 2, 2018. https://hbr.org/2018/03/when-empoweringemployees-works-and-when-it-doesnt.

Lee, Choonwoo, Kyungmook Lee, and Johannes M. Pennings. 2001. "Internal Capabilities, External Networks, and Performance: A Study on Technology-Based Ventures." Strategic Management Journal 22, no. 6-7: 615-40.

Lee, Mushin, and Joon Koh. 2001. "Is Empowerment Really a New Concept?" International Journal of Human Resource Management 12, no. 4: 684-95.

Liu, Dong, Hui Liao, and Raymond Loi. 2012. "The Dark Side of Leadership: A Three-Level Investigation of the Cascading Effect of Abusive Supervision on Employee Creativity." Academy of Management Journal 55, no. 5: 1187-1212. 
Lubit, Roy. 2002. “The Long-Term Organizational Impact of Destructively Narcissistic Managers." Academy of Management Executive 16, no. 1: 127-38.

Mohanty, Manoranjan. 1995. "On the Concept of 'Empowerment."” Economic and Political Weekly 30, no. 24: 1434-36.

Petrone, Paul. 2014. "How Chick-fil-A Hires: The Christian Way." Business 2 Community, July 26, 2014. https://www.business2community.com/ human-resources/chick-fil-hires-christian-way-0956114.

Richardson, Hettie A., Robert J. Vandenberg, Terry C. Blum, and Paul M. Roman. 2002. "Does Decentralization Make a Difference for the Organization? An Examination of the Boundary Conditions Circumscribing Decentralized Decision-Making and Organizational Financial Performance." Journal of Management 28, no. 2: 217-44.

Rigtering, J. P. C., G. U. Weitzel., and K. Muehlfeld. 2019. “Increasing Quantity without Compromising Quality: How Managerial Framing Affects Intrapreneurship." Journal of Business Venturing 34, no. 2: 224-41.

Rubinson, Joel. 2009. "Innovating Innovation: The Best Ideas Can Come from Anywhere." Fastcompany.com. Accessed March 18 ${ }^{\text {th }}, 2020$. https://www.fastcompany.com/1296086/innovating-innovationbest-ideas-can-come-anywhere

Ryan, Richard M., and Edward I. Deci. 2000. "Intrinsic and Extrinsic Motivations: Classic Definitions and New Directions." Contemporary Educational Psychology 25, no. 1: 54-67.

Sarasvathy, Saras D. 2001. "Causation and Effectuation: Toward a Theoretical Shift from Economic Inevitability to Entrepreneurial Contingency." Academy of Management 26, no. 2: 243-63.

Salerno, Joseph T. 1993. "Mises and Hayek Dehomogenized." Review of Austrian Economics 6, no. 2: 113-46.

Schyns, Birgit, and Jan Schilling. 2013. "How Bad Are the Effects of Bad Leaders? A Meta-Analysis of Destructive Leadership and Its Outcomes. Leadership Quarterly 24, no. 1: 138-58.

Shamir, Boas, Robert J. House, and Michael B. Arthur. 1993. "The Motivational Effects of Charismatic Leadership: A Self-Concept Based Theory." Organization Science 4, no. 4: 513-668. 
Siebert, Scott E., Seth R. Silver, and W. Alan Randolph. 2004. “Taking Empowerment to the Next Level: A Multiple-Level Model of Empowerment, Performance, and Satisfaction." Academy of Management Journal 47, no. 3: 332-49.

Shane, Scott. 2000. "Prior Knowledge and the Discovery of Entrepreneurial Opportunities." Organization Science 11, no. 4: 448-69.

Shane, Scott, and Venkataraman, S. 2000. "The Promise of Entrepreneurship as a Field of Research." Academy of Management Review 25, no. 1: 217-26.

Spreitzer, Gretchen M. 1995. "Psychological Empowerment in the Workplace: Dimensions, Measurement, and Validation." Academy of Management Journal 38, no. 5: 1442-1465.

Spreitzer, Gretchen M. 1996. "Social Structure Characteristics of Psychological Empowerment." Academy of Management Journal 39, no. 2: 483-504.

—. 2008. "Taking Stock: A Review of More Than Twenty Years of Research on Empowerment at Work." Pp. 54-72 in Micro Approaches, ed. Cary L. Cooper and Julian Barling. Vol. 1 of The SAGE Handbook of Organizational Behavior. Thousand Oaks, Calif.: SAGE.

Sullivan, Diane M., and Matthew R. Marvel. 2011. "Knowledge Acquisition Network Reliance, and Early-Stage Technology Venture Outcomes." Journal of Management Studies 48: 1170-93.

Witt, Ulrich. 1998. "Imagination and Leadership-The Neglected Dimension of an Evolutionary Theory of the Firm." Journal of Economic Behavior and Organization, 35, no. 2: 161-77.

— 1999. “Do Entrepreneurs Need Firms? A Contribution to a Missing Chapter in Austrian Economics." Review of Austrian Economics 11: 99-109.

Williamson, Oliver E. 1975. Markets and Hierarchies: Analysis and Antitrust Implications. New York: Free Press.

Yu, Tony Fu-Lai. 2001. "Entrepreneurial Alertness and Discovery." Review of Austrian Economics 14, no. 1: 47-63.

Zhang, Xiaomeng, and Kathryn M. Bartol. 2010. "Linking Empowering Leadership and Employee Creativity: The Influence of Psychological Empowerment, Intrinsic Motivation, and Creative Process Engagement." Academy of Management Review 53, no. 1: 107-28. 
. 2020. "The Entrepreneurial Opportunity Construct: Dislodge or Leverage?" Academy of Management Perspectives 34, no. 3. https:// journals.aom.org/doi/epdf/10.5465/amp.2017.0162.

Zahra, Shaker A. 2008. "The Virtuous Cycle of Discovery and Creation of Entrepreneurial Opportunities." Strategic Entrepreneurship Journal 2, no. 3: 243-57. 